\title{
The Process of Recruitment of Managers: Formal Management Education or Management Experience?
}

\author{
Cosmin Florin LEHENE 1
}

DOI: $10.24818 / \mathrm{mer} / 2021.12-02$

\begin{abstract}
In this paper we have analyzed 228 job announcements for the recruitment of managers within two online recruitment platforms most often used in Romania, named Ejobs and Indeed, regarding two important aspects: 1) recruitment of managers depending on management experience or formal management education and 2) recruitment of management graduates. The main objective is to describe the degree the practice of recruitment of managers takes into consideration the scientific advances in the management field and the formal management education. Through the mean of an archival data analysis research strategy, we found that for the recruitment of managers the companies asked almost exclusively for experience (91.2\%). The companies in our sample almost did not require the management education. Only in ten announcements the recruiters asked for a formal management educational degree. Moreover, only half of companies asked for management experience (56.1\%). Technical (39.4\%), industry (25.2\%) and working experience (7.7\%) are the other types of experience valued by the recruiters. Most companies asked for management abilities, in addition to experience, however (e.g influence), but they did not require that these abilities to be formed during a formal educational program. The future manager only should possess these abilities acquired from somewhere. The paper aims to contribute to the academic debate regarding the criteria used by companies to hire managers. In addition, the paper has a strong practical orientation aiming at improving the recruitment practice of managers and equipping the companies and organizations with management teams with adequate managerial knowledge, abilities, and competences.
\end{abstract}

KEYWORDS: recruitment of managers; management experience; management education; management graduates; managerial work

JEL CLASSIFICATION: $M$ S1; $M 53$.

\section{INTRODUCTION}

Human resources recruitment theory and practice recently became a specialized field of discussion among the management community, for both academics (AHRD, n.d.) and professionals (AAIMEA, n.d.; EAPM, n.d.). Along with the development of the human resources field over time, the scholars discussed the recruitment of personnel for an organization from many and diverse theoretical perspectives. For instance, the scholars approached the phenomena of recruitment of managers from a general management perspective (Bartol \& Martin, 1994; Manolescu, 2001; Osoian, 2006), organizational theory (Daft, 2010; Vlasceanu, 2003), organizational behaviour (Johns, 1996), information technology/e-HRM (Ivlev \& Triculescu, 2020), or psychology (Goleman, 1998). Specific research topics such as the influence of digitalization in conducting HRM activities and the

\footnotetext{
${ }^{1}$ Independent Researcher, Ph.D., Romania, lehenecosmin@ymail.com; corresponding author
} 
emergence of e-HRM (Ivlev \& Triculescu, 2020), HRM practices investigated in different industries such as the medical sector Petre (2020), or in the case of processing companies Ilies $\&$ Metz (2017), are in the central attention of modern human resources management research.

Even though the numerous scientific advancements in the human resources field, up to now, and at least as far as we know, there is no empirical evidence regarding if the practice of recruitment of managers is actually taking into account the scientific advances in the management field. Thus, in this paper we try to provide a detailed descriptive analysis of the phenomena of recruitment of managers, through confronting the existent theories in the management field with observational data. In short, we aim to test if the practice of managers' recruitment in Romania's business context is aligned with our basic knowledge and understanding regarding how the firms and organizations work (Bartol \& Martin, 1994; Drucker, 2007; Fayol, 1916; Lazar et al., 2010; Nicolescu \& Verboncu, 1997). The existent theories will be confronted with empirical data on the following topics: 1) the recruitment of managers based on experience or formal management education; 2) the degree the practice of managers' recruitment takes into consideration the formal management education; 3) the recruitment of management graduates for a management job.

From the beginning we would like to mention that the purpose is not to put the theoretical framework against the rigor of statistical tests, but rather to illustrate/describe how the practice of recruitment of managers is currently taking place, through confronting the theoretical framework with observational data (Hoffmann, 2007; Yin, 1984/2014; Welch et al., 2011). Even though there might exist scholars not agreeing with the fact that one theory can be tested with other methods, beyond the classical statistical tests, there are recent developments within the methodological literature describing how a theory can be tested with other methods as well. For instance, case studies (Ragin, 1997; Welch et al., 2011; Yin, 1984/2014). Szulanski and Jensen (2006), respectively (2011), even utilized a case study research strategy to test the theory of knowledge transfer in a multinational context with a single case study. The proverbial $N=1$. Gilbert (2005) also used a case study research strategy and eight cases to test and refine the theory of organizational inertia. We have implemented the same approach in this paper. The difference is that we aimed to confront the theory with archival data.

In order to facilitate the achievement of this goal we have resorted to a well-known definition of management stating that management means getting work done through other people and getting people together to accomplish desired goals (Birkinshaw \& Ridderstrale, 2017). This view of management is pretty much the same with that used thousands of years ago. It is as applicable today as it was in the past surviving the test of time (Birkinshaw \& Ridderstrale, 2017). Thus, in order to confront the theoretical framework against observational data, we turned to the most basic nature of managerial work (planning, organizing, coordinating, leading the people and supervising the activities conducted in organizations) [Fayol, 1916]. Even though within the business practice one might find other utilizations and interpretations of the concepts 'manager' and 'management' (e.g., time management, manager of portfolio of securities etc.), they are not related to the most basic nature of managerial work as described above (Lehene, 2019). Thus, this article is about managers (top, middle and firstline/operations) and their working activities and responsibilities in organizations.

Given the existent theories within the human resources management field we think the present paper might be valuable for several reasons. First, it aims to draw a healthier pattern for the recruitment of managers based on two independent, but complementary constructs: formal 
education and experience. Second, the framework might be valuable for the theory and practice since provides a solution for the integration into the workforce of management graduates. There is a huge problem regarding the integration of management graduates into the workforce, at least in Romania. Most management graduates end their studies and start working in other professions (e.g. cashier, customer support representative, worker in construction etc.) [Lehene, 2019]. Third, it aims to bring into the attention of recruitment practitioners the importance of considering the formal management education for all the managerial positions.

The paper has a strong practical orientation. The primary target/segment to which is addressed is the HR specialists and managers. It was designed mainly to improve (1) the process of recruitment of managers and (2) equipping of companies and organizations with adequate management teams.

The remainder of the paper continues as follows. We start with presenting the theoretical framework which will be used in the empirical part to discuss the problems/discrepancies observed in Romania's business context regarding the practice of recruitment of managers. Then, we present the research methodology adopted in this paper. Next, we analyze the empirical data, and we develop some practical implications for human resources practitioners.

\section{LITERATURE REVIEW}

\subsection{Recruitment of managers based on experience or formal management education (management knowledge and competences)}

The first problem we would like to discuss in this paper is the modality/practice through which many companies recruit managers in order to cover their available vacancies. The main assumption from which we start developing the argumentation in this paper is that most of the companies - at least those operating in Romania - are recruiting, then selecting managers, considering more valuable the experience than the formal management training - management knowledge and competences developed in the university. In more concrete terms, the future manager should possess certain years of management experience, in the best cases - more typically the companies ask for technical experience - and not depending how able and competent is the manager to administer the organization, even if he/she does not possess management experience. From the beginning we would like to mention that of course, the best situation is the situation in which the manager possesses both, management experience and formal management training (management knowledge and competences). Later in the paper we conceptualize this category of managers such as 'managers type one'.

Thus, we start with introducing two important distinctions/clarifications regarding the debate management experience vs. formal management education (management knowledge and competences). On the one hand, within organizations there can be managers possessing management experience and management knowledge and competences, resulting from the accumulation of experience. As the time passes, and the manager involves in the administration of the organization, he/she might become more able and competent to administer the activities and lead the people, even if he/she does not possess formal management training. On the other hand, there can be also managers possessing management experience, but without management knowledge and competences. In this situation, even if the time has passed, and the manager lead the division, unit, or the whole organization, he/she might not be accumulated management knowledge and competences, despite the accumulation of management experience. Or, in the worst case, the knowledge and 
'competences' accumulated might even be detrimental to the organizational management. The passage of time does not automatically guaranty that the manager has accumulated managerial abilities, knowledge, and competences (David, 2017). The idea is that the management experience and management knowledge and competences (abilities, skills) are not always correlated. We would say that they are, in general, complementary, but independent constructs.

Second, it is important to introduce the distinction between the concepts 'knowledge' and 'competences'. Knowledge, management knowledge in our case, is the data and information which becomes familiar to someone through engaging in repetitive experiences and training (Davidson \& Begley, 2012). On the other hand, competences reflect types of characteristics someone possess, permitting him/her to engage in a specific activity and obtaining superior performances (Goleman, 1998). At this level of analysis, another important distinction should be introduced between declarative knowledge and procedural knowledge. This distinction is particularly important for we as human beings, for education and learning since each type of knowledge is substantiated in a different region of the brain. These regions of the brain learn differently and need a different type of training (Davidson and Begley, 2012). In specific terms, declarative knowledge is the knowledge about things. Just because someone learns about, for instance, human resources recruitment, does not mean automatically that the person will be also able to recruit people for the organization. To put the theory at work, there is important another type of knowledge called procedural knowledge. Procedural knowledge is knowing how to utilize the declarative knowledge you have learnt in school or through specific educational programs (Davidson \& Begley, 2012; Mih, 2010/2018). In the context of our discussions, the management competences are related to the procedural knowledge. It means, the competences reflect the abilities and skills someone possess to utilize the declarative knowledge that he/she learnt in school or through a period of formal training.

As one can see, the social phenomena discussed in this paper is complex and is not always simple to differentiate between the management experience and management knowledge and competences since many times they might be shaping to each other. However, we believe this distinction is important because, as we have described above, the simple fact that the time has passed and the manager (e.g. an engineer occupying a management position without management formation) has accumulated management experience, does not mean automatically that the manager possess superior management knowledge and is more competent to administer the organization than a recent management graduate (Lehene, 2019). The fact that he/she could possess more working experience and better knowing the business practice, yes, but to the extent and speed the science is currently developing, if the management practitioners do not continue to update their management knowledge base and competences, in five or ten years they are totally overcome (David, 2017), by management graduates.

Therefore, depending the debate management experience vs. formal management training (management knowledge and competences), for the recruitment of managers, we can encounter at least the following situations: (1) a manager working already in the field for some years, having accumulated already management experience and having graduated from a management school as well; it means, a manager possessing both managerial experience and formal management training (management knowledge and competences); (2) a manager recently graduated from a management school, not possessing managerial experience but yes possessing formal management education (management knowledge and competences); (3) a manager working already in the field for some years, having accumulated managerial 
experience, but not possessing formal management education (management knowledge and competences); (4) a fourth category of managers might exist - managers neither possessing managerial experience nor formal management education (management knowledge and competences), but they might be present in organizations for other reasons (e.g. the firm is the firm of his/her parents, he/she might be liked by the employer, the firm might not encountered other more suitable managers etc.) (Table 1.)

Table 1. A heuristic classification of types of managers

\begin{tabular}{|c|c|}
\hline $\begin{array}{c}\text { Managers type one } \\
\text { Managerial experience and formal } \\
\text { management education (knowledge and } \\
\text { competences) }\end{array}$ & $\begin{array}{c}\text { Managers type two } \\
\text { No managerial experience but yes formal } \\
\text { management education (knowledge and } \\
\text { competences) }\end{array}$ \\
\hline $\begin{array}{c}\text { Managers type three } \\
\text { Only managerial experience, not also formal } \\
\text { management education (knowledge and } \\
\text { competences) }\end{array}$ & $\begin{array}{c}\text { Managers type four } \\
\text { No managerial experience and no formal } \\
\text { management education (knowledge and } \\
\text { competences) }\end{array}$ \\
\hline
\end{tabular}

Source: Authors' own elaboration

\subsection{Recruitment of managers with management education}

A second typical problem existent in the process of recruitment of managers is that many companies look to recruit managers, and they are not asking for formal management education such as a requirement (for example, MBA). Instead, many companies mention that the company is searching to hire new managers (operations managers, middle managers, and executives) and require technical (e.g. engineering) or other university level qualifications, partially related or even unrelated to management. For instance, one company might be looking to hire a manager and asking for technical competences and abilities. Is typical that these companies to ask in the announcement for a bachelor and/or a master's degree in engineering. The same could happen with other related fields to management such as psychology or sociology (for the recruitment of a human resource manager the company to ask for a psychology or sociology degree, not management degree) or finance (for the recruitment of a bank manager the bank to ask for a background in finance not in management).

However, this paper has not been written to nourish a fight between various educational programs and specializations offered by universities and colleges around the world. The main idea is that the companies and organizations should hire managers - or at least increase the attention devoted to hire managers - to management graduates. What we argue is that for this reason the students enroll in management educational programs, devote years from their professional career to study organizational management. Conversely, why do the universities offer management educational programs if the graduates will not work in their specialization after graduation?

Employing management graduates or increasing the attention devoted to hire management graduates for managerial positions/jobs everybody will win. For instance, the companies will have access to advanced management knowledge and competences, the management schools and colleges will accomplish their mission, and the management graduates will be more motivated and satisfied with their job, for which they prepare years in the university. The analogous is true in the public health sector where the medical doctors will occupy a medical position after graduation, or in public affairs where a graduate from the police academy will start working as a policeman (Lehene, 2019). Nobody could imagine that a medical or police 
student will start working after graduation in a supermarket such as a cashier. Of course, the future graduate will not become from the start a principal MD or a police general. Instead, he/she will occupy first a resident physician or a police inspector position, then, through time, he/she will advance throughout hierarchy. At the same time, nobody could imagine that you can work as a lawyer without formal law education or to become a medical doctor without a formal education in medical studies. The analogous might be true in management. Why can you work as a manager without formal management education/formation?

Lehene (2019) developed a framework for the integration in the workplace of management graduates. (Table 2.) In the empirical part, we are going to use this framework to analyze the data for this problem, with the mention that in the present paper we have included all the management graduates to be suitable to start working in a first-line management position. Even though the framework of Lehene (2019) is especially useful for providing guidance for the integration in the workforce of management graduates, a more realistic approach will be that all management graduates (managers type two) to start entering in the workforce in firstline management positions. Because of the lack of experience is hard to believe that some company will employ a recent young management graduate for a middle or executive position (but we do not exclude this possibility). Typically, for middle and executive management positions, the companies ask for several years of management experience. Therefore, the managers type one will be more suitable for these positions.

Table 2. Framework for integration in the workforce of management graduates

\begin{tabular}{|l|c|l|}
\hline $\begin{array}{c}\text { Level of } \\
\text { study }\end{array}$ & \multicolumn{1}{|c|}{ Position } & $\begin{array}{c}\text { Perspectives for long time } \\
\text { career development }\end{array}$ \\
\hline Bachelor & $\begin{array}{c}\text { First line managers } \\
\text { Team leader, operations managers, project } \\
\text { manager, head of office, shop manager }\end{array}$ & $\begin{array}{l}\text { Middle managers } \\
\text { Top management/Executives }\end{array}$ \\
\hline Master & $\begin{array}{c}\text { Middle managers } \\
\text { HR/marketing/production manager, Business } \\
\text { Unit/Division manager }\end{array}$ & Top management/Executives \\
\hline $\begin{array}{l}\text { Executive } \\
\text { MBA }\end{array}$ & $\begin{array}{r}\text { Top management/Executives } \\
\text { CEO, COO, Chief Strategy Officer, country } \\
\text { manager, plant manager }\end{array}$ & CEO \\
\hline
\end{tabular}

Source: Adapted from Lehene (2019), p. 157

\section{RESEARCH METHODOLOGY}

\subsection{Research strategy}

The main research goal in this paper is to describe/illustrate some problems/discrepancies between existent theories in the management field and the practice of recruitment of managers in Romania. In other words, there are some differences between what we currently know in the management field and observational data. Thus, we aim to achieve a descriptive purpose through an archival data/content analysis research strategy (qualitative and quantitative data will be analyzed). The approach we utilize in this paper is similar with that used in descriptive case studies (Bhattacherjee, 2012; Carlile \& Christensen, 2004; Yin, 1984/2014).

The research strategy implemented by us to identify the discrepancies/problems between existent theories in the management field and the practice of recruitment of managers has several advantages in comparison with other research strategies and methods. In comparison with a sociological inquiry (survey-based) the content analysis permitted us to investigate in depth the phenomena of recruitment of managers and to consider many variables of interest 
for a particular announcement. Moreover, in comparison with a survey-based, or even an interview-based sociological inquiry, the content analysis permitted us to investigate the phenomenon of recruitment of managers more objectively, since the data posted by recruiters on the recruitment platforms are quite objective (these are the requirements the candidates need to conform if they want the job). On the other hand, in comparison with a case study research strategy the content analysis conducted by us has the advantage that permitted us to consider various companies, operating in totally different industries.

Therefore, we use the empirical data for two main purposes. First, we aim to describe/illustrate with empirical data and examples the practice of managers' recruitment existent within the business context in Romania. Concretely, we aim to present that the problems/discrepancies between the existent knowledge in the management field and the practice of recruitment of managers are real and they are not based on the authors' subjective suppositions. Second, we use the empirical data to build our implications for the practice of recruitment of managers in order to improve the functioning of companies and organizations and improve equipping them with a management team with adequate managerial abilities.

The data analysis technique we utilize in this paper is relying on theoretical propositions, continuously iterating back and forth between the theoretical framework and empirical data (Eisenhardt, 1989; Yin, 1984/2014). As suggested by Eisenhardt and Graebner (2007) we have supported our analysis with concrete examples from the practice for each pattern observed. In order to discuss the main patterns, we also resorted to a 'cross-cases' data analysis technique (Eisenhardt, 1988; 1989; Miles \& Huberman, 1984/1994). Regarding data collection, we stopped collecting data at the point the possibility to gain new insight/knowledge from empirical data was minimal. While researchers are collecting data, they arrive at an inflection point from which on gathering new data is too costly and does not add any more value. This concept is called within the methodology literature 'empirical saturation' (Eisenhardt, 1989).

Regarding the research methodology adopted in this paper it is also important to mention that we have resorted to a positivistic view of the social world. More concretely, the existent management theory and subsumed theoretical framework developed in this paper are viewed from a positivistic philosophical position. Philosophical position is quite important since influences the entire research process and the manner the researchers think about the social phenomenon being studied (Welch \& Piekkari, 2017). The researchers investigating the social phenomena from a positivistic view of the social world are searching for objectivity and causality and for the development of hypotheses which are generalizable among various settings. They rely heavily on statistics and quantitative data analysis. Moreover, positivist social researchers think there is a single reality which can be discovered, controlled, and predicted, they think the observations are possible to be realized without the personal involvement - the personal involvement in research is view as a source of bias - and they think the results could be obtained time and context-free (Welch et al., 2011; Welch \& Piekkari, 2017). Thus, positivists argue that there is possible to identify the cause of a specific social phenomena and then generalize the finding to other social contexts (Bhattacherjee, 2012; Welch et al., 2011; Welch \& Piekkari, 2017; Wynn \& Williams, 2012). 


\subsection{Concepts operationalization}

For this study, we have selected the two online platforms, probably the most often used in Romania for the recruitment of managers, named Ejobs and Indeed. We randomly searched for all the recruitment announcements which had in their title the concept 'manager'. All the announcements returned by the platform containing the concept 'manager' were analyzed. We have also considered similar concepts often used interchangeable with the concept 'manager', such as team leader, unit or plant director, head of operations etc. We have considered and analyzed the recruitment of managers for all the hierarchical positions (first-line managers, middle managers, and top managers/executives). In total, 114 recruitment announcements posted on the portal Ejobs and 114 posted on the recruitment platform Indeed were analyzed. We have carefully revised all the 228 announcements several times, depending to the subject of discussion. Regarding the hierarchical position, we have analyzed the valid recruitment announcements for 122 first-line/operations managers, 38 announcements for the recruitment of middle managers, and 10 announcements for the recruitment of top managers/executives.

We started the analysis with identifying the hierarchical position of the future manager (firstline/operations manager, middle manager, or top manager/executive). In the first category, we have included the team leaders, the supervisors, the project managers, the store managers, all the positions being responsible for directing and supervising the operators/non-managerial personnel. More specifically, in this category we have included the managers in charge of organizational structures not having other detailed structures/teams. Within the middle management category, we have included the divisional managers, the plant managers, the managers responsible for a certain function within the firm (e.g., marketing). Basically, all the managers having other managers/first-line managers directly reporting to them. In other words, the managers of organizational units not having other subunits for which are responsible other managers. Within the top management/executive category, we have included the CEOs, the general managers of Romanian companies, the country managers of MNCs, the Chief Strategy Officers etc. All the managerial positions being responsible for the smooth running of the overall company.

For the first problem discussed in the theoretical part we coded the information depending if the company recruits based on management experience or formal management education (management knowledge and competences). Almost all the companies in our sample mentioned as a requirement a certain type of experience, for the recruitment of managers, being managerial, technical, industry and/or working experience. Given the diversity of types of experience asked by the recruiters, we have operationalized and separated the variable 'previous experience' using the following categories: 1) management experience (e.g. two years team coordination/leadership experience; three years experience as a store manager; one year experience working as a project manager); 2) technical experience (e.g. five years working in finance or as an accountant; two years working in marketing or sales; one year experience working as an engineer); 3) industry specific experience (e.g. five years working in retail/construction/banking/call-center industry); 4) working experience (e.g. three years of working experience no matter the domain).

We have operationalized the variable 'formal management education' using a nominal level measure with four categories: 1) management education; 2) economics or business education (other specializations than management - finance, accountancy, marketing etc.); 3) other university level education (sociology, politics, engineering, law etc.); 4) university education - no matter the domain. The distinction between the third and fourth category is that for the 
third category the recruiter mentioned in the announcement the specific qualification required, while in the fourth category the recruiter only mentioned that the future holder of the position needs to be educated at university level, without mentioning the qualification or the domain of qualification.

For the second problem, we have classified the recruitment announcements in three categories according to the same coding scheme mentioned above: (1) management education; (2) economics or business education (other specializations than management - finance, marketing, accountancy etc.); (3) other university level education (sociology, politics, engineering, law etc.); (4) university education - no matter the domain.

\section{DATA ANALYSIS AND DISCUSSION}

\subsection{Recruitment of managers based on experience or formal management education (management knowledge and competences)}

The first problem identified in the practice of recruitment of managers is that many companies look to recruit managers based on management experience (in the best case) and/or technical experience (in other cases), rather than on formal management training (how much managerial knowledge the future occupant of the position has and how competent is the future manager in order to administer the company, division or team that he/she needs to manage).

From the total of 228 recruitment announcements analyzed we have excluded from our analysis 58 recruitment announcements since they do not reflect a management position, even though the recruiters mentioned in the announcement that the company looks to recruit a 'manager'. This action resulted in 170 valid announcements for the recruitment of managers. Regarding the topic a management or a non-management job, we are not going to insist in this paper with details. We would only say that we have employed a view of management at the most basic level. Thus, we have evaluated if there is a management position based on two criteria: 1) the future occupant of the management position has direct people reporting to him/her and 2) the future occupant of the management position performs the following activities: plan, organize, lead, and control the activities conducted by at least a team of people.

As one can see in the Table 3 in almost all the recruitment announcements the recruiters asked for previous experience (in 155 announcements, representing 91.2\% from the total of 170 valid announcements for the recruitment of managers) such as managerial, technical, industryrelated, or simple working experience. Only 15 companies ( $8.8 \%$ from the total) did not mention as a requirement that the future manager should possess previous experience (managerial, technical, industry-related or working experience). The most common type of previous experience asked by the companies in our sample was the management experience (87 announcements), followed by technical experience (61 announcements), industry-related experience (39 announcements) and in 12 announcements the recruiters mentioned that the future manager should possess only working experience. It is important to mention that we observed that in most announcements there was formed a mix of experience composed from two, or sometimes three categories, from the four categories of experience presented above. Few companies asked only for a single specific category of experience.

We also mention that for the recruitment of managers based on formal management education, we have considered only the management education offered in universities as adequate to describe the formal management education, no matter being a bachelor or 
master's degree. Even though in many business, engineering or sociology schools the students learn during one or two semesters some management disciplines (e.g. human resources management, general management, organizational behavior etc.) they are not licensees to work as managers, they are not licensed managers (Lehene, 2019). For this reason, in this paper we have considered only the licensed managers for the variable 'formal management education'.

Table 3. Recruitment of managers based on experience or formal management training

\begin{tabular}{|c|c|c|c|c|c|c|c|}
\hline \multirow{2}{*}{$\begin{array}{l}\text { Criteria for } \\
\text { recruitment }\end{array}$} & \multirow{2}{*}{ Experience } & \multirow{2}{*}{$\begin{array}{l}\text { No } \\
\text { experience } \\
\text { required }\end{array}$} & \multicolumn{4}{|c|}{ Type of experience } & \multirow{2}{*}{$\begin{array}{l}\text { Formal } \\
\text { management } \\
\text { education }\end{array}$} \\
\hline & & & Managerial & Technical & Industry & Working & \\
\hline \multicolumn{8}{|c|}{$\begin{array}{c}\text { Total no. of announcements analyzed: } 228 \text { (114 Ejobs and } 34 \text { Indeed) } \\
\text { There was not a managerial position: } 58 \text { announcements ( } 24 \text { Ejobs and } 34 \text { Indeed) } \\
\text { Remaining valid announcements: } 155\end{array}$} \\
\hline \multicolumn{8}{|l|}{ Ejobs } \\
\hline $\begin{array}{l}\text { Number of } \\
\text { cases }\end{array}$ & 85 & 5 & 49 & 38 & 23 & 8 & 5 \\
\hline \multicolumn{8}{|l|}{ Indeed } \\
\hline $\begin{array}{l}\text { Number of } \\
\text { cases }\end{array}$ & 70 & 10 & 38 & 23 & 16 & 4 & 5 \\
\hline Total & 155 & 15 & 87 & 61 & 39 & 12 & 10 \\
\hline
\end{tabular}

Source: Authors' own elaboration

In our sample, almost all organizations asked in the recruitment announcement for a certain type of working experience (155 announcements from 170 valid recruitment announcements) and almost none/very few companies asked for formal management training (only in 10 announcements from the 170 valid recruitment announcements). Instead, the companies required many types of university level education. We are not going to enter in detail regarding the types of education required by companies since we have an entire subchapter devoted to this topic. Some companies, however, is true that very few, mentioned that the future manager should possess an accredited project management diploma. Even though these short-term management related training programs are useful and can be assimilated such as management education, for the purposes of this paper, we have considered only a formal educational program offered by universities, no matter being a bachelor or a master's degree.

\subsubsection{Main patterns}

As we have seen above, what the companies in our sample required for the employment of managers was at the best management experience - or technical experience and industry experience in other cases - and not formal management education (management knowledge and competences). In other words, what is required to become a manager is experience, not management knowledge and competences. This is the main pattern we have observed after our data analysis. For example, a large MNC in the retailing industry (DIY stores segment) asked for the recruitment of a Store Manager for "2 years experience in management, experience in project management, and mentioned that the commerce and logistics experience will be considered advantage". There was nothing mentioned within the announcement regarding the management formation.

Beyond this main pattern, next we are going to discuss three specific patterns observed. (See also the Table 6.) First, regarding the specific experience required, many companies asked for some years of technical or industry-related experience, plus management experience (the 
candidate should have worked some years in a management position). For example, for the recruitment of an Area Manager for a company in the retailing industry (deluxe tobacco segment) the company mentioned the following requirements:

"3 years experience in retailing; Minimum 1 year experience in a management position".

The second specific pattern observed is that many companies asked for a technical qualification or other university level education (not management education), plus management experience. For example, for the recruitment of a Store Manager for a large $\mathrm{MNC}$ in the cosmetics industry the company mentioned the following requirements within the recruitment announcement:

"3-5 years of specialty retail make-up/fashion store management experience; Graduate of Higher Education".

Another example. For the recruitment of a General Manager for an international company in the fertilizer industry the recruiters asked for the following requirements:

"The most suitable candidate is:

- Senior manager with minimum 10 years of experience in the agribusiness;

- University graduate in agriculture or economics with previous exposure in ag-inputs or ag-commodities".

All the announcements in the patterns above required experience (technical, industry related or working experience), complemented with management experience. In addition to the experience requirements, as a third specific pattern, the announcements of the most companies in our sample were more complex asking also for management skills, in addition to the experience requirements. But the problem is that in all these cases nothing was mentioned in the announcement regarding the management formation/management studies. For example, for the recruitment of a Plant General Manager for a company in the manufacturing industry the recruiters asked for the following requirements:

"Plant GM is a demanding role which requires all-round business knowledge and managerial skills:

Experience in an operational role in a manufacturing business (production unit or plant), packaging experience preferred; A total of 10 years' experience in manufacturing, with minimum 5 years of managerial experience; Performance improvement experience and proven track record against manufacturing KPIs in a leadership role; Experience in leading P\&L of the organization, very good understanding of manufacturing business financial management.

$[\ldots]$

Qualification in a technical/engineering discipline an advantage".

Another example. A large MNC in the mobile phone industry asked for three years technical experience, plus management competences and abilities such as:

"Influence - skilled at managing, directing and motivating others towards success; Able to manage people in a multicultural environment; Communication with impact - must be able to communicate with efficiency on crisis situation and on reporting".

Or, for the recruitment of a Store Manager for a retailing company in the cosmetics industry the recruiters asked for the following requirements:

"Four years experience in retail; Two years experience in a management position; Excellent organizing, communication, and relational abilities; Planning abilities and being able to accomplish objectives on medium and long term". 
As one can observe in all the announcements described above, the companies in our sample required various types of working experience, complemented with management experience, plus management competences and abilities, but there was nothing there mentioned regarding the management education. In all these announcements, the companies required some management competences and abilities - the future occupant of the position must possess these management competences and abilities - but the companies did not require to be formed during a formal educational program.

\subsubsection{Discussion}

In conclusion, we can observe that the companies in our sample did not require management formation/education. There can be at least two main explanations for this phenomenon. The first explanation is that among the business practitioners the management knowledge, competences and abilities are regarded as something learnt in the job, acquired with the accumulation of experience and the years spent in the job, firm, or industry, and not as something being learnt in school or through a period of formal training. This approach encountered within the business practice is called in the management field 'common sense management', or 'empirical management' (Lehene, 2020). Is a typical managerial approach developed at the common sense understanding of people, is very simple and intuitive. Our predecessors used this management approach one or two hundred years ago when the management of the firm was based on the intuition, charisma, and experience of the founder (Popa et al., 2013). We have now modern management theories explaining in detail how the companies and organizations should be managed. The fact that the experience is valuable and helpful no doubt about this, but is the case for the management scientific knowledge, management science and evidence-based management to be prioritized.

In short, what currently matters within the business practice - at least in Romania - for the recruitment of managers is the technical, industry or managerial experience, plus the future manager possessing common-sense management competences and abilities. The management competences and abilities are required (e.g. skilled at managing, directing, and motivating others towards success) but the companies do not require to be formed during a management educational program. The candidate only should possess those abilities, acquired from somewhere. In the terminology of this paper, the type of managers mostly required by the companies in our sample is the 'managers type three' (see the Table 1).

The second possible explanation for the patterns above (the practice of commonsense/empirical management) is derived from a more basic level, specifically from how the human mind works, from the field of science called clinical psychology. We, as human beings, have an innate psycho-social need for predictability. The human mind needs meaning and significance (David, 2017). Since there is a need in all organizations for promotion, for the most prolific, effective, and productive employees to promote, to advance in the organization (or older employees in some organizations), most companies promote/recruit in/for management positions depending on the accumulation of experience, rather than management education. From the bottom up, as you advance throughout the hierarchy, more years of experience are required (managerial, technical, or industry as we have seen in our sample). For this reason the recruiters ask for experience and not management education for the recruitment of managers: it makes sense, it gives meaning and significance. Moreover, more years of experience you possess automatically more knowledgeable and competent you are seen (so you qualify as a middle manager or executive). For a first-line/operations management position the recruiters ask for few years of experience and for an executive 
position for many years of experience. No matter the formal management education in this paradigm, even is not mentioned.

\subsubsection{A possible shift in the practice of recruitment of managers}

As we can see from the analysis above, what is required to become a manager is experience, plus common-sense management competences and abilities. We would say that for all these cases the management graduates are equal (or even more suitable) to managers which only possess experience (no matter the domain of experience). (Of course, as mentioned above, assuming the management graduates being suitable entering into the workforce in first-line management positions.) The management graduates can also be more suitable in comparison with those candidates only possessing a technical background (or other university level education), technical experience and without management formation, since, very important, is a management position, not technical position. For the managers type three (the most required category in our sample, representing $95 \%$ from all the announcements) is the case to complement the experience with formal management education/training (e.g. Executive MBA, MSc in Management, even a formal Project Management program) if you want to become a good manager (manager type one). Otherwise, you will face the risk to be overcome by the management graduates (managers type two), since they currently learn modern management methods, techniques, tools, and study updated management knowledge based on data from research. An experienced manager or engineer (without formal management education) better knows the industry and business practice, masters more technical skills, and perhaps has developed already a system of relationships. But we refer in this paper only to management knowledge and competences (according to data from research) to administer a firm, business unit, department, or team.

We have already said that experience on the one side, and knowledge and competences on the other side are independent constructs. For this reason, we have elaborated this paper. They are not always correlated; you need both to be outstanding. Of course, if the organization needs to hire a manager the best option is to hire a manager possessing both formal management education (management knowledge and competences) and management experience (managers type one). No doubt about this. But, in the case there is not a candidate with this requirement, the second option, such as an alternative, the companies might ask for formal management education (management knowledge and competences) (managers type two), rather than management experience (managers type three). The main idea is to take in consideration the formal management education at least equally important as the same numbers of years of management experience. For example, for the recruitment of a project manager the companies might ask for three years of project management experience or a Bachelor of Science in management. In short, this paper makes a call for a shift in the practice of managers hiring, to replace the existent practice (almost all the companies asked for managers type three) with a healthier practice passing from managers type one to managers type two and/or managers type three as a second option. (Table 4.)

Table 4. New practice for the recruitment of managers

\begin{tabular}{|c|r|}
\hline Recruiting practice in the present & New recruiting practice \\
\hline Managers type three & Managers type one $\rightarrow$ Managers type two \\
& $\rightarrow$ Managers type three \\
\hline
\end{tabular}

Source: Authors' own elaboration 


\subsection{Recruitment of managers with management education}

The second problem identified in the practice of human resources recruitment, and related with the topic above, is that many companies and organizations recruit, then select managers, without formal management education. First, it is important to mention that in various announcements the recruiters mentioned two, or sometimes three categories of formal education, not only one (e.g. management education, economics - non-management education, other university level qualification). On the other hand, the recruiters mentioned in many announcements that the future candidate only should be educated at university level, without a formal qualification being mentioned. In our sample, there were also announcements in which the recruiters did not mention a formal education as a requirement for the future manager.

\subsubsection{Main patterns and discussion}

In the Table 5, one can see that only in 10 recruitment announcements from the total of 170 valid recruitment announcements $(5.8 \%)$ the recruiters asked for a formal management education. Instead, the companies in our sample required many other types of formal education. The most required category of formal education was, surprisingly, "formal education not mentioned in the announcement" consisting of 70 announcements, followed by "university level education, no matter the specialization" (43 announcements) and "other university level qualifications" (45 announcements). It seems that "the economics nonmanagement education" (27 announcements) and "the management education" (10 announcements) were the categories of formal education less important for the companies in our sample, regarding their preferences for the recruitment of managers.

Table 5. Distribution of managers' recruitment announcements depending education

\begin{tabular}{|c|c|c|c|c|c|}
\hline $\begin{array}{l}\text { Candidate } \\
\text { education }\end{array}$ & $\begin{array}{l}\text { Management } \\
\text { education }\end{array}$ & $\begin{array}{c}\text { Economics } \\
\text { non- } \\
\text { management } \\
\text { (e.g. finance, } \\
\text { accountancy, } \\
\text { marketing) }\end{array}$ & $\begin{array}{c}\text { Other } \\
\text { university } \\
\text { level } \\
\text { qualifications } \\
\text { (e.g. } \\
\text { sociology, } \\
\text { engineering, } \\
\text { law) } \\
\end{array}$ & $\begin{array}{c}\text { University } \\
\text { level } \\
\text { education, no } \\
\text { matter the } \\
\text { specialization }\end{array}$ & $\begin{array}{c}\text { Formal } \\
\text { education not } \\
\text { mentioned in } \\
\text { the } \\
\text { announcement }\end{array}$ \\
\hline \multicolumn{6}{|l|}{ Ejobs } \\
\hline $\begin{array}{l}\text { Number of } \\
\text { announcements }\end{array}$ & 5 & 15 & 24 & 25 & 36 \\
\hline \multicolumn{6}{|l|}{ Indeed } \\
\hline $\begin{array}{l}\text { Number of } \\
\text { announcements }\end{array}$ & 5 & 12 & 21 & 18 & 34 \\
\hline Total & 9 & 27 & 45 & 43 & 70 \\
\hline
\end{tabular}

Regarding this chapter surprises the large number of companies recruiting managers based only on higher education, no matter the qualification (any qualification is ok). As many as in 43 recruitment announcements. Perhaps, more surprising is the large number of companies looking to recruit managers and not mentioning the formal education as a 
prerequisite/criterion for the recruitment, even though there was the case of a high responsibility position. As many as in 70 recruitment announcements the recruiters did not require the formal education as a prerequisite/criterion for the recruitment. The most important education for managers, the management education, is the least important for the companies in our study, according to our data. Only in 10 announcements from the total of 170 valid announcements $(5.8 \%)$ the recruiters mentioned the formal management education as a prerequisite/criterion. So, the question is why is this social phenomenon happening?

To give explanation to this phenomenon we now need to return to our discussion in the previous subchapter. Our assumption is that the management education (in the form of management knowledge, competences, and abilities) is regarded as being something learnt in the job, which develops with the years spent in the company and industry and with the accumulation of experience, and not as being something learnt in school. As mentioned previously, what is practiced currently within the Romania's business environment is the empirical management/common-sense management used one hundred years ago. To be a good manager - in this paradigm - you need to be an engineer, accountant, sociologist, finance specialist, operational worker, technician (no matter the qualification/formal education) and with the accumulation of years in the job/company you will be suitable to become a manager. Again, the accumulation of experience in the job/company is important not the management formation (scientific management knowledge, competences, and abilities). For this reason, so many companies do not ask for management education. What matters in this paradigm is the experience. For example, a company in the engineering field asked for the hiring of a Field Service Manager for a candidate which should be:

"A graduate of a Technical University (Electronics, Automation, Mechatronics,

Mechanical Engineering) and possess previous management experience (min 4 years)”.

The recruiters mentioned many managerial abilities and knowledge within the body of the announcements of various companies, however. The idea is that the companies did not mention that these abilities and competences should be formally developed during an educational program. Rather, it was assumed by the recruiters that these abilities develop with the accumulation of experience in the job/industry, and/or with the accumulation of years in a managerial position. They are taken from granted as we have mentioned earlier, as being something learnt in the job. For example, for the recruitment of a Store Manager the company did not mention the formal education in the announcement, but in the job description (what the future manager should do) described the following activities:

"Leading, organizing and optimizing the store functioning; Coordination, development and recruiting of the team members; Accomplishment of objectives; Permanent monitorization of competitors; Firm representation in relation with the external stakeholders."

As one can see, all the activities pertain to the basic nature of manager's work, requiring managerial abilities to realize them, but within the recruitment announcement there was nothing mentioned regarding the management formation/education. This is another evidence confirming that the management knowledge and abilities are regarded as something learnt in the job, developed with the accumulation of experience and not as being something learnt in school or through a period of formal training.

Moreover, in the Table 5 we can observe that the most required type of experience by the companies in our sample was the management experience ( 88 announcements), but in most of these cases the recruiters did not require the formal management education (only in 10 announcements the recruiters mentioned the formal management education). Thus, 
confirming our statement above: managerial knowledge, abilities and competences are regarded as something learnt in the job, developed with the accumulation of experience and not as being something educated.

Another important pattern observed is that almost in all the cases, even though the recruiters asked for a technical education or other university level education (engineering, psychology, law etc.) the activities which should be carried out by the future manager they were all management related activities (not engineer, not lawyer, not psychologist related activities etc.). Therefore, there is a discrepancy/dysfunctionality between the education required by the companies in our sample and the job to be done. For example, a company in the food production industry asked for the recruitment of a Production Subunit Manager (a firstline/operations management position) for technical (engineering) education/technical university education. But when we have analyzed the activities the future manager needs to do, they were all, without exception, management related activities (not technical). We cite from the recruitment announcement:

"The person who will occupy the position will have the following responsibilities: coordinates, guides, supervise and is responsible for the entire activity of the unit; allocate the employees to the jobs and elaborate the working schedule; monitors that the installations and all the resources to be utilized at maximum capacity; has responsibility for the realization of the production monthly programs; has responsibility for the quality assurance at the standards required by customers; choses the best solutions for production' optimization; monitors and evaluate the employees performances".

As one can see, all the activities involve basic managerial work - planning, organizing, leading, and controlling the activities carried out by a team of people, to accomplish organizational goals. They are not engineering related activities. The future occupant of the Production Management position does not need to perform activities related to building engines, bridges, buildings, appliances, ships etc. More than that, all the competences required to perform the activities above, they are all taught in management schools in academic disciplines such as Production Management, Operations Management, HR Management, Quality Management etc.

Given the discussions above, drew upon the empirical analysis between the proposed theoretical framework and the practice of managers' recruitment in Romania, the main findings are presented in the Table 6 , accompanied by a list of practical implications for the human resource managers and specialists (Table 7).

\section{CONCLUSIONS}

In this paper we aimed to describe/illustrate some problems/discrepancies between the existent theories in the management field and the practice of recruitment of managers. To facilitate the accomplishment of this research goal we have resorted to a view of management at the most basic level (planning, organizing, leading, and controlling). As we have seen in the empirical part, there are several problems/discrepancies between existent management theories and observational data, between what we know in the academic community regarding how the firms and organization work - and what is actually implemented by practitioner managers.

First, we have observed that the companies and firms in Romania are not interested to hire managers possessing formal management education. In general, it seems that they are not interested or are very low interested in the formal education (in 70 announcements the 
recruiters even not mentioned the formal education as a criterion for the recruitment of managers). Instead, what the human recruitment specialists and managers value for the recruitment of managers (no matter being a first-line/operations, middle, or executive management position) is experience. Not only the management experience is important for the recruitment of managers but also other type of experience (technical, industry, or simply working experience). For the recruitment of managers for the first line-management positions there are required few years of experience and for the middle management and executive positions there are required many years of experience.

Table 6. Main findings

\begin{tabular}{|c|c|}
\hline $\begin{array}{c}\text { Problem/discrepancy } \\
\text { between theory and practice }\end{array}$ & Main patterns \\
\hline $\begin{array}{l}\text { Recruitment based on } \\
\text { experience vs. formal } \\
\text { management education }\end{array}$ & $\begin{array}{l}\text { From the total number of } 170 \text { valid announcements, in } 155 \\
\text { announcements the recruiters asked for experience. Only in } 15 \\
\text { announcements the recruiters did not require experience. On the } \\
\text { other hand, only in } 10 \text { announcements the companies required } \\
\text { formal management education. } \\
\text { Beyond this: } \\
\text { - In a pattern, the recruitment was based on different types of } \\
\text { working experience (technical, industry, working) + } \\
\text { management experience. } \\
\text { - In a pattern, the recruitment was based on other university } \\
\text { level education (not management education) + management } \\
\text { experience. } \\
\text { In a pattern, the recruitment was based on experience } \\
\text { (technical, industry, working, management) + management } \\
\text { skills and abilities (common-sense management abilities); } \\
\text { the recruiters asked for management skills and abilities but } \\
\text { there was not a requirement to be acquired from formal } \\
\text { management education; they only should be acquired from } \\
\text { somewhere. }\end{array}$ \\
\hline $\begin{array}{l}\text { Recruitment based on formal } \\
\text { management education vs. } \\
\text { other specializations }\end{array}$ & $\begin{array}{l}\text { From the total of } 170 \text { valid announcements, only in } 10 \\
\text { announcements the companies required formal management } \\
\text { education. Thus, in } 160 \text { recruitment announcements the companies } \\
\text { required other university level education, or they were even not } \\
\text { mentioning the formal education in the announcement. Beyond this: } \\
\text { - The practice of recruitment of managers was conceptualized } \\
\text { as common-sense management (university level education - } \\
\text { any kind of education) + experience. } \\
\text { - The companies required management abilities but there was } \\
\text { not a requirement to be acquired during a period of formal } \\
\text { management training; they only should be acquired from } \\
\text { somewhere. } \\
\text { In many announcements, we have observed that the } \\
\text { recruiters asked for technical education or other type of } \\
\text { university level education, but after we have performed the } \\
\text { job analysis resulted that there was the case of management } \\
\text { activities, requiring management abilities to be done and not } \\
\text { technical abilities. }\end{array}$ \\
\hline
\end{tabular}

Source: Authors' own elaboration

Second, we have also observed that the recruitment practitioners value for the hiring of new managers the management abilities. Many companies explicitly mentioned in the 
announcement that the future manager must possess abilities such as influence or team leadership abilities in addition to experience. But as we have observed through studying various recruitment announcements posted by companies operating in Romania these management abilities do not need to be developed during a formal management educational program. The future manager only should possess these abilities acquired from somewhere. Another way to look at this phenomenon is that the development of the managerial abilities it is assumed to be developed with the accumulation of years and experience spent in the company/industry and is not view as something being educated in school or through a period of formal training.

Third, we have observed that there is a discrepancy between what the companies require in terms of formal education and the work to be done. For example, many companies require an engineering degree but the work to be done by the future manager is related to planning, organizing, leading the people, and controlling the activities of a team of people or department, requiring management abilities to be done such as influence or team leadership.

Table 7. Implications for human resources recruitment practice

Implications for practice

- Recruiters should ask for the recruitment of managers for formal management education/training (management knowledge and competences developed in the university or research institutes).

- Recruiters should look to hire managers possessing formal management education and management experience (managers type one).

- Otherwise, recruiters should look to hire managers possessing formal management education but not also management experience (managers type two) or they should look for managers without formal management education but possessing management experience (managers type three).

- Recruiters should ask, primarily, for the recruitment of managers for management experience rather than industry, technical and/or working experience.

- Recruiters should increase the attention devoted to hire management graduates and look primarily for management graduates, in comparison with graduates from other specializations, for the recruitment of managers.

- Recruiters should ask for the recruitment of managers for abilities and competences formed during participation in formal educational programs (abilities and competences supported by evidence - abilities and competences which really work), rather than asking for common sense management abilities and competences (acquired from somewhere which might even be detrimental to the organizational functioning).

Source: Authors' own elaboration

In conclusion, the managerial approach implemented by the companies in our sample is called commonsense/empirical management. This managerial approach worked well in the past at the point the management of the firm was based on the charisma and intuition of the founder. What we argue is that, in the modern era, the companies and organizations need to consider and prioritize the new scientific advances and discoveries in the management science if they want to become really competitive. There are now well establish management theories based on data from research - postulating how a firm or organization should be managed. Every day, month and year management scientists strive to publish, monitor and read the new discoveries in the management field, they update their knowledge regarding how the companies and organizations should work. They disseminate these new discoveries in universities during formal management educational programs. Thus, the management students have access to new findings and to new ways to manage organizations, they learn new 
models, concepts, and ways to manage organizations during formal management educational programs. Then, they take this knowledge with them after graduation and implement it in the companies where they are going to work. The main danger of not requiring formal management education by one side, and not hiring management graduates by the other side, is the companies to miss important scientific advances and developments in the management field.

Therefore, to prevent this lack of competitiveness by the company side and also by academia side, based on the empirical data analysis conducted above we have proposed here a list of practical implications for human resources practitioners. In short, we think the companies could modify their managers' recruitment conduct according to the practical implications developed in the Table 7 . We think that the companies employing the ideas developed in this paper (e.g. they will consider for the recruitment of managers the formal management education) can increase their functioning and they even might be increasing their performances.

In this paper we refer to management graduates to people of all ages not only to young students. For example, one employee might be working in the same company for ten or fifteen years, then enroll in a MSc. in Management or EMBA if he/she wants to promote in a management position. The company might even support the educational taxes if the employee wants to return and promote in a management position into the same company.

Other important conclusion, this time particularly important for the academic management community, is that the chances/opportunities the companies offer to management graduates are almost inexistent. Paradoxically the fact that the management students learn years in university management disciplines, after graduation the chances to enter the workforce in their specialization are almost zero (given the analysis of recruitment announcements conducted by us). As we have seen in our study, by one side, all the companies require experience (not formal management education), and by the other, the companies and firms ask for other types of education (e.g. technical, marketing, finance or social sciences in general). To redress this imbalance, we have proposed an alternative but healthier solution: the companies should consider the number of years of management studies at least equally valuable to the same number of years of management experience. Management academia should improve and strengthen its ties and partnerships with companies and should strive for the recruitment of managers for management graduates from their programs (management graduates for management positions). Otherwise, a simple question may arise: why do universities offer management educational programs to their students? Nobody wants to spend years to study a specific university level program which does not offer perspectives after graduation and become a cashier or at the worst case unemployed.

\section{REFERENCES}

AAIM Employers' Association. (n.d.). Talent Acquisition/Recruiting. Retrieved from: https://aaimea.org/services/talent-acquisitionrecruiting/.

Academy of Human Resource Development. (n.d.). About AHRD. Retrieved from: https://www.ahrd.org/page/about_ahrd_2.

Bartol, K. M. \& Martin D.C. (1994). Management. 2nd ed. USA: McGraw-Hill.

Birkinshaw, J. \& Ridderstrale, J. (2017). Fast/Forward: make your company fit for the future. California: Stanford University Press. 
Bhattacherjee, A. (2012). Social Science Research: Principles, Methods, and Practices. Florida: Textbooks Collection.

Carlile, P. R. \& Christensen, C.M. (2004). The cycles of theory building in management research. Harvard Business School. Working Paper, 5. Retrieved from https://www.hbs.edu/faculty/ Publication\%20Files/05- 057.pdf.

Daft, R. (2010). Understanding the theory and design of organizations. Mason, OH: South-Western Cengage Learning.

David, D. (2017). Tratat de psihoterapii cognitive si comportamentale. Iași: Polirom.

Davidson, R. \& Begley, S. (2012). The Emotional Life of Your Brain: How Its Unique Patterns Affect the Way You Think, Feel, and Live - and How You Can Change Them. USA: Hudson Street Press.

Drucker, P. (2007). The practice of Management. Classic Drucker Collection. UK: Elsevier.

Eisenhardt, K. M. \& Bourgeois, L.G. (1988). Politics of strategic decision making in high velocity environments: Toward a mid-range theory. Academy of Management Journal, 31, 737-770.

Eisenhardt, K. M. (1989). Building theories from case study research. Academy of Management Review, 14(4): 532-550.

Eisenhardt, K. M. \& Graebner, M. (2007). Theory building from cases: Opportunities and

Challenges. Academy of Management Journal, 50(1), 25-32.

European Association for People Management. (n.d.). Purpose. Retrieved from: https://www.eapm.org/purpose.

Fayol, H. (1916). Administration industrielle et generale: prevoyance, organization, commandement, coordination, controle. Paris: H. Dunod et E. Pinat.

Gilbert, C.G. (2005). Unbundling the Structure of Inertia: Resource Versus Routine Rigidity. Academy of Management Journal, 48(5), 741-763.

Goleman, D. (1998). Working with emotional intelligence. London: Bloomsbury.

Hoffmann, W. (2007). Strategies for Managing a Portfolio of Alliances. Strategic Management Journal, 28, 827-856.

Ilies, L. \& Metz, D. (2017). Influence of the Human Resources Practices on the Employees Attachment. Empirical Study within the Companies in the Processing Industry. Management and Economics Review, 2(2), 183-194.

Ivlev,I. \& Triculescu, M. (2020). E-HRM - A Mean to Increase HRM Role in Organizations - A Comprehensive Literature Review". Proceedings of the $14^{\text {th }}$ International Management Conference "Managing Sustainable organizations" (pp. 789-799). Bucharest: Bucharest University of Economic Studies.

Johns, G. (1996). Organizational Behavior. Understanding and Managing Life at Work. 4th ed. New York: Harper Collins Publisher.

Lazar, I., Ilies, L., Mortan, M., Popa, M, Lungescu, D. \& Veres, V. (2010). Management. ClujNapoca: Risoprint.

Lehene, C.F. (2019). Adaptation of an educational ideal and refinement of the didactic strategies used in the management pedagogy in Romania. Educatia 21 Journal, 17, 151-163.

Lehene, C.F. (2020). A Quest for Evidence-Based Interventions/Practices (EBMIs). Derivation and Testing of Management Intervention/Practices in Randomized Clinical Trials (RCTs). Proceedings of the 14th Edition of International Management Conference. Bucharest: Bucharest University of Economic Studies.

Manolescu, A. (2001). Managementul resurselor umane. Bucharest: Editura Economica.

Mih, V. [2010] (2018). Psihologie educationala. Cluj-Napoca: Asociatia de Stiinte Cognitive din Romania.

Miles, M. \& Huberman, M. [1984] (1994). Qualitative Data Analysis: an expanded sourcebook. 2nd ed. California: SAGE Publications.

Nicolescu, O. \& Verboncu, I. (1997). Management. Bucharest: Editura Economica.

Osoian, C. (2006). Managementul resurselor umane. Cluj-Napoca: Presa Universitara Clujeana.

Petre, A.G. (2020). Study on the Influence of Human Resources Management on Patient Satisfaction. Proceedings of the $14^{\text {th }}$ International Management Conference "Managing Sustainable organizations" (pp. 857-869). Bucharest: Bucharest University of Economic Studies. 
Popa, M., Lungescu, D. \& Salanta, I. (2013). Management: Concepte, Tehnici, Abilitati. Cluj-Napoca: Presa Universitara Clujeana.

Ragin, C.C. (1997). Turning the Tables: How Case-Oriented Research Challenges Variable-Oriented Research. Comparative Social Research, 16, 27-42.

Szulanski, G. \& Jensen, R.J. (2006). Presumptive Adaptation and the Effectiveness of Knowledge Transfer. Strategic Management Journal, 27, 937-957.

Szulanski, G. \& Jensen, R.J. (2011). Sumantra's Challenge: Publish a Theory-testing Case Study in a Top Journal. In R. Marschan \& C. Welch (Eds.), Rethinking the Case Study in International Business and Management Research (p. 107-123). Cheltenham: Edward Elgar.

Vlasceanu, M. (2003). Organizatii si comportament organizational. Iasi: Polirom.

Welch, C., Piekkari, R., Plakoyiannaki, E. \& Paavilainen-Mantymaki, E. (2011). Theorizing from case studies: Towards a pluralist future for international business research. Journal of International Business Studies, 42, 740-762.

Welch, C. \& Piekkari, R. (2017). How Should We (Not) Judge the 'Quality' of Qualitative Research? A Re-assessment of Current Evaluative Criteria. International Business. Journal of World Business, 52(4), 714-725.

Wynn, D. \& Williams, C.K. (2012). Principles for conducting critical realist case study research in information systems. MIS Quarterly, 36(3), 787-810.

Yin, R. K. [1984] (2014). Case Study Research: Design and Methods. 5th ed. Thousand Oaks: Sage. 